\title{
Lumen
}

Selected Proceedings from the Canadian Society for Eighteenth-Century Studies

\section{Improvised Patronage: Jacob Tonson and Dryden's Linguistic Project}

\section{Catherine Fleming}

Volume 36, 2017

URI : https://id.erudit.org/iderudit/1037856ar

DOI : https://doi.org/10.7202/1037856ar

Aller au sommaire du numéro

Éditeur(s)

Canadian Society for Eighteenth-Century Studies / Société canadienne d'étude du dix-huitième siècle

ISSN

1209-3696 (imprimé)

1927-8284 (numérique)

Découvrir la revue

Citer cet article

Fleming, C. (2017). Improvised Patronage: Jacob Tonson and Dryden's Linguistic Project. Lumen, 36, 95-111. https://doi.org/10.7202/1037856ar d'utilisation que vous pouvez consulter en ligne. 


\title{
Improvised Patronage: Jacob Tonson and Dryden's Linguistic Project
}

\author{
Catherine Fleming \\ University of Toronto
}

The eighteenth-century bookseller is now recognized as a middleman through whom works reach the public, as a reflector of public taste, and as a cultural figure who slowly ousted the aristocratic patron in shaping and supporting literary production. ${ }^{1}$ The bookseller Jacob Tonson was one of the more important of these figures, using his publishing house and political relationships to support rising authors. Even before Tonson gained his social connections, however, he played an important part in literary culture. Tonson has usually been viewed as a patron in the sense of a provider of social and political introductions, as Stephen Bernard shows in his recent examination of Tonson as a Whig publisher. ${ }^{2}$ Because scholars like Bernard have focused on Tonson's extraordinary capabilities and connections, however, they have failed to fully examine the ways that, merely by being an independent bookseller who paid his authors rather than requiring them to fund their own writing, Tonson began to establish the type of relationship that would eventually take the place of traditional patronage by the aristocracy.

1. Don-John Dugas, Marketing the Bard: Shakespeare in Performance and Print 1660-1740 (Columbia: University of Missouri Press, 2006), 83-139; William St. Clair, The Reading Nation in the Romantic Period (Cambridge: University of Cambridge Press, 2007), 375; Dustin Griffin, Literary Patronage in England, 1650-1800 (Cambridge: Cambridge University Press,1996), 9-16.

2. Stephen Bernard, "Introduction," in The Literary Correspondences of the Tonsons (Oxford: Oxford University Press, 2015), 66. 
Tonson's relationship with John Dryden began as a business matter. When Tonson agreed to publish Dryden's translations, however, he began an association that ended in his taking the place of a traditional patron to Dryden's long-standing desire to improve and promote the English language. In the process, they set a precedent for a new form of publication and an increased reliance on the bookseller. Dryden's relationship with Tonson began a trend that culminated in Johnson's declaration, in the 1750s, that his bookseller, Andrew Millar, was his patron and the "Maecenas of the age." 3 This transition to the centrality of the market and the seller was, as Dustin Griffin points out, not a "sudden change from a patronage economy," but a slow movement in which booksellers began to supplement traditional patrons. Early in his career, Dryden benefited from all of the three main forms of patronage, which Deborah Payne categorizes as "titles or entitlements," "access to positions" and social circles, and gifts of money from wealthy or titled supporters. ${ }^{5}$ He supplemented this income by writing plays for the King's Men, a position not directly reliant on a patron but which he gained in part through his court connections and the court's reliable attendance at his plays. After the Glorious Revolution, however, Dryden turned to other sources of income.

Dryden's reliance on Tonson began significantly earlier than the mid eighteenth century where scholars, often citing Alexander Pope and Samuel Johnson as examples, typically place the shift from an elite patronage model to a new literary marketplace. Dryden's experience shows how an early commercial venture evolved organically into a relationship that neither figure would have recognized as traditional patronage but that allowed Dryden comparable support. This empowered him to lead a group of writers to refine the English language through translation, appropriation, and adaptation and to promote the creation of a native English canon.

3. Harry M. Solomon, The Rise of Robert Dodsley: Creating the New Age of Print (Southern Illinois University Press, 1996), 297, n. 2; James Boswell, Boswell's Life of Johnson, ed. George Birkbeck Hill (Oxford: Clarendon Press, 1934), I: 287-88.

4. Griffin, Literary Patronage in England, 1650-1800, 10.

5. Deborah C. Payne, "Patronage and the Dramatic Marketplace under Charles I and II," The Yearbook of English Studies 21 (1991), 139. 
Historically, scholars have considered the young Jacob Tonson's acquisition of Dryden's writings as a coup for the bookseller. ${ }^{6}$ Tonson's editions of Dryden's translations began a lucrative series that continued for years after Dryden's death. Moreover, they established Tonson as Dryden's personal bookseller during a period when, as Johnson later remarked, Dryden's reputation "was such that his name was thought necessary to the success" of every literary work and "he was engaged to contribute something," to almost every publication. ${ }^{7}$ At the same time, as Bernard demonstrates, during the 1670 os Dryden's previous bookseller, Herringman, stopped publishing new books, and Dryden needed a new bookseller. ${ }^{8}$ His relationship with Tonson enabled Dryden to finally act on a desire which he had put off for years. Beginning with the 1680 edition of Ovid's Epistles by several hands and continuing in the loose verse Miscellanies of 1684 , author and bookseller collaborated in a project that was to link their names together as authors, editors, and compilers, and which offers an early example of the bookseller as patron.

Many scholars talk of Pope as the populariser of subscription publishing, a slightly more egalitarian form of authorship, but, in fact, Dryden was one of the first authors to take up a monetary relationship with his bookseller. Dryden was the first of his calibre and prestige to publish on an equal footing with a bookseller and without the support of a patron. His Virgil, which even before its publication created a stir in England and on the continent, has been a focal point for studies of the transition between a patronage-based economy and a new, more broadly-based establishment where cultural capital was supported by and transformed into a cash-producing market. ${ }^{10}$ Of course, as Pat

6. Kathleen Lynch, Jacob Tonson: Kit-Cat Publisher (Knoxville: University of Tennessee Press, 1971), 17-34.

7. Samuel Johnson, Lives of the English Poets, ed. George Birkbeck Hill (Oxford, 1905), I: 372.

8. Stephen Bernard, "Henry Herringman, Jacob Tonson, and John Dryden: the Creation of the First Modern Publisher," Notes \& Queries 62. 2 (2015), 275.

9. Pat Rogers, "Pope and his Subscribers," Publishing History 3 (1978): 7-36; Terry Belanger, "Publishers and Writers in Eighteenth-Century England," in Books and Their Readers in Eighteenth-Century England, ed. Isabel Rivers (New York: St. Martin's Press, 1982), 21; W.A. Speck, "Politicians, Peers, and Publication by Subscription 1700-1750," in Books and Their Readers in Eighteenth-Century England, 48.

10. John Barnard, "Early Expectations of Dryden's Translation of Virgil (1697) in England and on the Continent," Review of English Studies 50 (1999), 196-203; 
Rogers discusses, subscription publishing is also a form of patronage, and John Barnard shows how this patronage worked in relation to Dryden's Virgil, ${ }^{11}$ but the expansion of the patrons of a work from a single aristocrat or a small group to a wider circle was part of a larger movement which took patronage out of the hands of the aristocracy.

After the Glorious Revolution, Dryden was forced to rely on Tonson as an intermediary who could supply him with the income he had formerly enjoyed from the court. ${ }^{12}$ In doing so, he publicly created an altered patronage market in which the middling classes of society could participate. Even before the Glorious Revolution, however, when Dryden was not so reliant on Tonson as a source of income, Tonson's support and shrewd analyses of the literary market allowed Dryden to write and circulate many of his pet theories. Although Dryden continued to receive support from patrons throughout his life, Dustin Griffin shows how Dryden's dedications demonstrate increasing autonomy during the later years of his life. ${ }^{13}$ Tonson's interest in translation and occasional poetry as a money-making venture allowed Dryden the opportunity to put into practice the first steps of a project that he had long supported but for which he was unable to find an aristocratic patron, although he had been working to promote his linguistic project since the early 1660 .

Dryden's early translations were part of a wider attempt to improve his native language and to show that English was capable of equalling any other language. Early in his career, he publicly supported translation in rhyme, hoping to compare English and Latin verse, but he was

Alexandre Beljame, Men of Letters and the English Public in the Eighteenth Century, 1660-1744, Dryden, Addison, Pope, ed. Bonamy Dobrée, trans. E. O. Lorimer (London: Routledge and Kegan Paul, 1948), 354-86.

11. Pat Rogers, "Family, Kinship, and the Evidence of Subscription Lists: Dorothy Stanley and Arcadia Moderniz'd," Review of English Studies 66. 275 (2015), 501-19. John Barnard, "Dryden, Tonson, and the Patrons of The Works of Virgil (1697)," in John Dryden: Tercentenary Essays, ed. Paul Hammond and David Hopkins (Oxford: Oxford University Press, 2000), 175.

12. Studies report that Dryden earned between $£_{910}$ and $£_{1,400}$ from his Virgil, more than enough to support an Esquire for three years. See Barnard, "Dryden, Tonson, and the Patrons of The Works of Virgil (1697)," 177, 239; "Large and Small Copies of Dryden's The Works of Virgil (1697): Jacob Tonson's Investment and Profits and the Example of Paradise Lost (1688)," Papers of the Bibliographical Society of America 92 (1998): 259-71; and "Dryden, Tonson, and Subscriptions for the 1697 Virgil," Papers of the Bibliographical Society of America 57 (1963): 129-51.

13. Griffin, Literary Patronage in England, 1650-1800, 70-98. 
unable to find a long-term source of patronage for this project. He was part of the 1664 "committee for improving the English language"14 appointed by the Royal Society, but the committee soon dissolved, due in part to the plague that swept London later that year and scattered its members. In 1679, Dryden was considering the creation of an academy built around the lines of the French Académie, and in the dedication to his Troilus and Cressida he asks Sunderland, then the Southern Secretary, for support, outlining what would be necessary for an English academy to equal that of the French.

The Earl of Roscommon picked up this focus, and his academy flourished for a brief period in the 1680 s. ${ }^{15}$ This academy echoed the regret Dryden expressed in his dedication to The Rival Ladies, "that, speaking so noble a language as we do, we have not a more certain Measure of it, as they have in France,"16 and focused primarily on improving and sustaining the beauties of the English language through translation. As a member of the academy, Dryden used translation to import words from other languages and to compare English to Latin and Greek poetry. In 1921, Oliver Emerson declared that "to Dryden alone belongs the first public advocacy of an Academy for England, after that of France had taken up its labours," 17 and while this should not be taken to mean that he was its only driving force, he was certainly an early and deeply invested part of the group. Dryden's dedication to this linguistic project and his view of it as an important social and political undertaking can be seen in the fact that he published "some of his most important reflections on the English language, translation, the classical Latin and Greek heritage, and the role of the poet" in occasional, commendatory poems and dedications promoting the works of other members of this group. ${ }^{18}$ I. 499 .

14. Thomas Birch, The History of the Royal Society of London (London, 1756),

15. Katsuhiro Engetsu, "Dryden and the Modes of Restoration Sociability," in The Cambridge Companion to Dryden, ed. Steven Z. Zwicker (New York: Cambridge University Press, 2004), 192.

16. John Dryden, The Works of John Dryden, ed. Vinton A. Dearing, H. T. Swedenburg, Alan Roper, et al. (California: University of California Press, 1990), VII: 98.

17. Oliver Farrar Emerson, John Dryden and a British Academy (London: Published for the British Academy by H. Milford, Oxford University Press, 1921), 3.

18. Paul Hammond, The Making of Restoration Poetry (Cambridge: D. S. Brewer, 2006), 147 . 
Dryden's attachment to the Earl of Roscommon and his informal academy is part of his larger concern with translation as a way of shaping language. Especially in the early years of his career, he seems to have seen translation more as a means to reform the English language through greater connection with other languages, especially Latin from which he often borrowed words and turns of phrase, than as simply a vehicle for monetary gain. In this context, the prefaces and dedications to his translations, which focus on translation theory, encourage other translators to follow in his footsteps.

Dryden's contributions to the Art of Poetry show one way he advertised the improvement of the English language. Tonson's advertisement claims "I saw the Manuscript lye in Mr. Dryden's Hands for above Six Months, who made very considerable Alterations in it," especially altering the text "to apply the Poem to English Writers," rather than praising only French authors. These alterations were, Tonson insisted, "entirely done by Mr Dryden," a claim which shows Dryden's investment in the process. ${ }^{19}$ This advertisement also shows Dryden's concern for his native literature. Focusing on English names and authors allows Dryden to promote these writers and to smooth the way for future writers in the field. His linguistic project was inspired by an admiration for French methods, and his work on this translation offered him a chance to not only help a fellow writer but also improve his own knowledge of Boileau's work through close study and to endorse a text that he hoped would shape the future of English poetry. He was proud of the English language, claiming in his Virgil that, although he cannot hope to surpass the work of his fellow English poets, he "will boldly own" his superiority over "either the French or the Italian," writers. ${ }^{20}$

In the context of this focus on language, Dryden's participation in the Tonson edition of Ovid's Epistles, with its lengthy preface on translation and the ways in which translation works to highlight the beauties of both the original and the English language, is an important public step toward realizing his goals. John Barnard mentions that while Tonson "was responding to what he sensed was a literary trend," when he published the Miscellanies, he "was also creating an audience" for

19. Dryden, Works, II: 368 .

20. Dryden, Works, V: 325 . 
Dryden's translations and starting a new literary form. ${ }^{21}$ Despite the important role Tonson played in their creation, he attributed these volumes and their successors to Dryden's editorial hand, capitalizing on the former poet laureate's name. Picking up on this language, later miscellanies were created "On Dryden's foundations," as John Nichols explains, expanding Dryden's influence on later readers. ${ }^{22}$

Tonson may have focused on gaining an audience, but Dryden had additional concerns. The Miscellanies were not only a commercial venture but also a medium for Dryden's linguistic project, offering a place to publish and share translations from the classics. They also gave him a way to encourage the careers of younger poets. The poets featured in the Miscellanies used their association with Dryden and the readership his sponsorship gained for their translations to further their own careers, and in doing so they became the new generation of English poets that Dryden had hoped to support. Addison's career offers one example of how the Dryden-Tonson pair helped aspiring poets by including them in their translation ventures.

Addison's first and second publications, a series of Latin verses in praise of King William, appeared in 1689 and 1690 in collections sponsored by his college at Oxford. He broke into the larger field of publication in the Dryden-Tonson Miscellany Examen Poeticum with a short poem in praise of Dryden. The following year, apparently impressed by his poetry, Dryden included a long translation from the Georgics and several short poems by Addison in the 1694 Annual Miscellany. Although two translation projects suggested to Addison by Tonson failed to come to fruition, Dryden introduced him to Congreve, who in turn led Addison to his patron, Charles Montagu. Addison then contributed an anonymous essay on the Georgics to Dryden's Virgil. This was both a repayment of his debt to the older poet and a shrewd career move. While the majority of the reading public may not have known the author of this essay, Addison's new patron, Montagu, and

21. John Barnard, "Dryden, Tonson, and Virgil," 209.

22. John Nichols, A Select Collection of Poems; With Notes, Biographical and Historical (London: J. Nichols, 1780-82), II: vii. See Michael F. Suarez SJ, "Poetic Miscellanies," in Books and their Readers in Eighteenth-Century England: New Essays, ed. Isabel Rivers (London and New York: Leicester University Press, 2001), $236-44$, for more on the way miscellanies copied and cited each other as foundations and exemplars of the genre. 
those authors and patrons in both Dryden's and Tonson's circles would have recognized and credited Addison for his work. Moreover, Dryden cites Addison in his "Postscript to the Reader" as a translator in his own right, and one whose work "has put me to sufficient pains to make my own not inferior to his." ${ }^{23}$ This is high praise, and Dryden's commendation of the young and rising writer shows Dryden's eagerness to support Addison in his career.

In sponsoring Congreve, both Dryden and Tonson involved themselves much further than in their more typical interactions with Addison, but Dryden's literary relationship with Congreve is complicated by pressing questions of authorship, influence, and mutual debts. Despite these factors, the relationship between these three men offers an example of the way that Dryden and Tonson mutually supported young poets. ${ }^{24}$ As with Addison, Dryden saw him first, revising and supporting Congreve's first play, The Old Batchelor. ${ }^{25}$ Through Dryden, Congreve met Tonson, who concurred in Dryden's belief that Congreve was Dryden's natural successor, leading both writer and bookseller to cultivate the young man.

Dryden invited Congreve to be the signatory and witness to many of his contracts with Tonson, allowing Congreve to experience for himself the relationship between bookseller and literary giant. ${ }^{26}$ Eager to secure the young author for his publishing house, Tonson cultivated Congreve's friendship as well as his poetry, a move that Dryden supported in part by sending messages to Congreve in his letters to Tonson, including both Tonson and Congreve within his social circle and assuming and encouraging continued connections between the two men. During this time, Tonson invited the young poet to live as a lodger in his house, where Congreve remained for a period between

23. Dryden, Works, VI: 810.

24. See, among others, Harold Weber, "A 'double Portion of his Father's Art': Congreve, Dryden, Jonson and the Drama of Theatrical Succession," Criticism 39.3 (1997), 359-82; Robert D. Hume, The Development of English Drama in the Late Seventeenth Century (Oxford: Clarendon Press, 1976): 381-90; and Robert Markley, Two Edg'd Weapons: Style and Ideology in the Comedies of Etherege, Wycherley and Congreve (Oxford: Oxford University Press, 1988), 200.

25. Susan Fitzmaurice "Servant or patron? Jacob Tonson and the language of deference and respect," Language Sciences 24 (2002), 252.

26. Julie Stone Peters, Congreve, the Drama, and the Printed Word (Stanford: Stanford University Press, 1990), 49. 
1693 and $1695 .{ }^{27}$ Congreve's friendship with the bookseller continued even after Dryden's death in 1700, and Tonson was an important influence on the 1710 edition of Congreve's works, both encouraging his censorship and, as D. F. McKenzie explains, enabling him to pioneer an innovative new publication style. ${ }^{28}$

Dryden and Tonson collaborated in acting as sponsors to both Addison and Congreve in these poets' early careers, giving them opportunities and introducing them to other poets, publishers, and patrons. Without detracting from their own interests, the pair's Miscellany volumes and the group translations of Ovid, Juvenal, Persius, and Plutarch which Dryden organized also helped to support the kind of translating collaborative that Dryden hoped would take on the linguistic questions of his age. The Miscellany volumes especially "permitted new, young poets to get into print early in their careers and in the company of their elders," 29 forwarding their careers considerably. Dryden, a professional writer who was very aware of how his own reputation worked, hoped that this would help them to a position where his protégés would mold the language through collaboration with ancient writers.

Importantly, although Dryden "published some of his most important reflections on the English language" in poetic and prose prefaces to his translations and to the works of friends, including his poem on Roscommon's "Essay on Translated Verse," neither he nor Tonson ever collected these elsewhere, leaving them to stand in connection with his translations and the apparently minor poems and works of his friends and unofficial clients. ${ }^{30}$ This suggests that Dryden felt these works were important enough and likely to remain current for long enough that his words were safely preserved within their pages. It also, given his references to these prior works in the Virgil which was his most acclaimed production, shows his desire to promote these publications. Readers desiring a full knowledge of Dryden must, this means,

27. J. M. Treadwell, “Congreve, Tonson, and Rowe's 'Reconcilement," Notes and Queries (1975), 268.

28. D. F. McKenzie, Making Meaning: "Printers of the Mind" and Other Essays (Boston: University of Massachusetts Press, 2002), 225-27.

29. David Wykes, A Preface to Dryden (London: Longman Publishing Group, 1977), 47 .

30. Hammond, The Making of Restoration Poetry, 147. 
also buy, and hopefully read, the translations, essays, and poems that he promoted.

These works, in conjunction with Dryden's large sphere of influence and the numerous prefaces he wrote, helped to establish a new canon of older writers to complement Tonson's focus on modern English poets. ${ }^{31}$ Dryden's focus on Chaucer, Shakespeare, and Milton as the three great English poets helped to foster a growing sense of English national poetry even as his ostensible project focused on classical authors. ${ }^{32}$ Dryden's praise and support of his fellow translators through his prefaces and by inclusion in 'his' Miscellanies or by introduction to his bookseller served the double purpose of supporting both classical and English poets.

Supporting his fellow translators was always a part of Dryden's goal, and he took ownership of Tonson's edition of Ovid's Epistles in his lengthy preface, but the first of his Miscellany Poems may have seemed less important than the Epistles when Dryden first agreed to publish as part of it. There is no introduction to this work, only a table of contents which orders the miscellaneous translations by the work they are translated out of, and lists the names of the authors next to their poems. Although Dryden's name is attached to the pieces he contributed, and he is the primary contributor to the volume, his role "cannot be determined" 33 and the title attributes the work merely to "the most Eminent Hands" that Tonson could collect. ${ }^{34}$

A year later, when Sylvae was published, Dryden had realized what this series of publications could do, and his attitude had changed. Sylvae, though another miscellany by multiple hands, is very much Dryden's production. "Dryden made suggestions for work to be published, solicited contributors, wrote prefaces, translated - in short, 'edited'," this volume, ${ }^{35}$ insisting to Tonson that "I am resolvd we will have nothing but good" writers, in a subtle criticism of Tonson's own

31. Harold Love, "Refining Rochester," Harvard Library Bulletin NS 7. 1 (1996), 40-49; Keith Walker, "Jacob Tonson, Bookseller," The American Scholar 61 (1992), 424-30.

32. Hammond, "Is Dryden a Classic?" 8.

33. Swedenburg et al., The Works of John Dryden, II: 374.

34. Miscellany Poems (London: printed for Jacob Tonson, 1684).

35. Walker, "Jacob Tonson, Bookseller," 426. 
choices. ${ }^{36}$ Not only is this one of the earliest examples of modern editing, although neither Tonson nor Dryden used this term, the time that these men spent in planning their volume shows the importance which they now attached to the project.

At the same time, Dryden depicts the project as larger than he is. While he defended the two imitations in the Epistles in order to ameliorate the admission that he himself has "transgress' $d$ the Rules which I have given," ${ }^{37}$ his relationship to the pieces in Sylvae is much more complex. He is too close, he declares, to some of the authors to praise them "without suspicion of partiality" and others he has not read. ${ }^{38}$ This simultaneous claim and admission illustrates Dryden's involvement in the project. Tonson published the second edition of the Miscellanies as a set "Published by Mr. Dryden," 39 and there seems to have been little argument about the attribution. Dryden was often closely involved with his publications, complaining that "the Printer is a beast, and understands nothing I can say to him of correcting the press," and insisting on dealing with Tonson directly. ${ }^{40}$ But Dryden's declaration that that he has "not perus'd" some of these translations claims only limited editorial intervention and implies that this project has expanded beyond the writing of his coterie.

Dryden's translations set a trend which he encouraged others to follow. "Ovid's Epistles, advertised on 6 February 1680, contains the first of Dryden's translations to appear in print" and from this point until the end of his life and career "the great bulk of his nondramatic poetry" in addition to some of his prose work, consisted of translation. ${ }^{41}$ Dryden used his Miscellanies to test his audience, experimenting with different levels of faithfulness to or deviation from his original. In the frame of a miscellany volume, these pieces allowed him to explore new methods and authors without committing himself to a large project like the Virgil. During the last twenty years of his life, Dryden partici-

36. Dryden, Letter to Tonson, August/September 1684, in The Literary Correspondences of the Tonsons, 88.

37. Dryden, Works, I: 118.

38. Dryden, Works, V: 325 .

39. Hugh MacDonald, John Dryden: A Bibliography of Early Editions of Drydenia (reprint. London: Dawsons of Pall Mall, 1966), 70.

40. Dryden, Letter to Tonson, December 1697, in The Literary Correspondences of the Tonsons, 130.

41. Swedenburg et al., The Works of John Dryden, I: 323. 
pated in many of Tonson's translation projects, writing prefaces for Tonson's edition of The Art of Painting and a new translation of Lucian. He also continued to seek out and encourage collaborative projects, and Tonson's multiple-hands edition of Tacitus brings together a group of translators and benefits from Dryden's introduction in the same way as the Epistles.

The last of the Miscellanies published in Dryden's lifetime, the Fables shows how Tonson's business plans complemented Dryden's linguistic goals. In this book, Dryden ties together a series of translations and modernizations to create a history of English writers who can be read alongside the classical authors. His reclamation of Chaucer, which establishes Chaucer as part of Dryden's literary ancestry, is an especially pivotal move in expanding and contributing to the "deliberate canon formation" that John Barnard sees Tonson as carrying out during this period. ${ }^{42}$

The majority of Tonson's editions focused on modern English poets or on classical translations like the Virgil which he commissioned Dryden to produce, but the Fables fleshes out the period between classical antiquity and the seventeenth century. This publication includes not only Dryden's modernised translations of Chaucer but also the first roman-letter publication of Chaucer's original poetry in England. By publishing Chaucer's poems in roman letters, this publication made his writing, as David Hopkins points out, much more accessible than the previous blackletter editions that had served to highlight his antiquity and obsolescence. ${ }^{43}$ Moreover, Dryden's preface links Chaucer to more respected authors, creating a chain of authorial lineage that begins with Chaucer, runs through Spenser, who "more than once insinuates that the soul of Chaucer was transfus'd into his body," and ends in Milton, already available in Tonson's edition of Milton's Paradise Lost to which Dryden had contributed a laudatory poem. ${ }^{44}$ Having

42. John Barnard, "Introduction," in The Cambridge History of the Book in Britain, ed. John Barnard and D. F. Mackenzie (Cambridge: Cambridge University Press, 2002), 22.

43. Previous editions of Chaucer had presented his work in blackletter, setting them physically apart from contemporary works much as facsimile copies do today. See David Hopkins, "Editing, Authenticity, and Translation," in John Dryden: Tercentenary Essays, ed. Paul Hammond and David Hopkins (Oxford: Oxford University Press, 2000), 356.

44. Dryden, Works, VII: 25. 
established this English lineage, Dryden positions it in relation to the ancient writers. "Having done with Ovid for this time," he says, "it came into my mind that our old English poet, Chaucer, in many things resembled him, and that with no disadvantage on the side of the modern author."

Dryden does not compare Chaucer with the great epics of the ancient world as he did Milton. He chooses his author and his texts carefully, putting Ovid, known for luxuriant prose on romantic themes, next to "The Knight's Tale," “The Nun's Priest's Tale," and “The Character of a Good Parson." Admitting that he is "studious to promote the honor of [his] native country," Dryden spends the remaining discourse working to do just that. First briefly comparing Chaucer to Ovid, he then compares him to Boccaccio, also in this volume, who "refin'd" his "mother tongu[e]" as Chaucer refines Boccaccio, and Dryden in turn refines Chaucer. ${ }^{45}$ He then moves on to make a similar comparison between Homer and Virgil before returning to Chaucer and Ovid and ending his essay by praising Chaucer and defending his decision to translate the poet. This structure, like Dryden's praise of Milton, helps to establish a new English canon. He claims that Chaucer is "the father of English poetry, [and] so I hold him in the same degree of veneration as the Grecians held Homer or the Romans Virgil," encouraging English authors to take pride in the national language and linguistic heritage. ${ }^{46}$

At the same time, he supports and encourages alterations to that heritage. Dryden emphasizes his changes to what he calls "a rough diamond," that "must first be polish'd, ere he shines" and his hopes that his protégés will help him to continue the refining process that Chaucer began through comparison to great works in other languages. ${ }^{47}$ This preface, part of the collaboration between Tonson and Dryden, creates an English past equivalent to the great classical writers expands Tonson's editions of great English poets, which Thomas Bonnell sees as beginning the formation of our modern English canon, from Milton and the great modern writers. ${ }^{48}$

45. Dryden, Works, VII: 25, 43, 25.

46. Dryden, Works, VII: 335.

47. Dryden, Works, VII: 40.

48. Thomas Bonnell, The Most Disreputable Trade: Publishing the Classics of English Poetry 1765-1810 (Oxford: Oxford University Press, 2008), 39-40. 
Most of the translations Dryden wrote for Tonson from the $168 \mathrm{os}$ to the end of his life show this preoccupation with theories of language, and the Miscellanies were at the centre of this work. Even in his Virgil, commissioned by Tonson as a stand-alone piece, Dryden continually references his Miscellanies in the notes, discussing translations of various pieces by others which were published in the Miscellanies and even referring his reader there to read Rochester's notes in lieu of providing his own full set. ${ }^{49}$ Aware of the cultural and political value his Virgil had taken on even before its publication, Dryden takes steps to ensure that those of its readers who are interested and educated enough to read and benefit from its notes return to his fullest expressions of translation theory in the Tonson Miscellanies.

Dryden's work in his Virgil continued several strains of his larger project. His dedication to the Aeneis discusses his "Trade both with the Living and the Dead, for the enrichment of our Native Language"50 and his importation of Latinate words into the English language. Although he claims that the point is "not worth dispute," he spends several pages of the notes, defending his right to create or to adopt words. He asserted this ability in the dedication to the Æneis, defending himself against the claim that "I latinize too much" by declaring that he only does so when he cannot find an English word that is "significant and sounding." ${ }^{51}$ Dryden's notes, however, focus on the need to improve the English language rather than simply defending his own practice. He skims over his reasoning for the invention of particular words, claiming that he might as easily and as well have used an already existing word, in order to focus on his overall practice. Claiming that the Italian from which he takes his new words is "a polish'd Language," he creates an implicit contrast to his "Native Tongue" which still needs to be refined. Dryden's desire for linguistic change guides his reader's attention not to specific usages but to his overarching desire to import beautiful or useful words from the Latin to improve the English language. ${ }^{52}$ In the Virgil, with its reputation and market well established even before publication, Dryden makes this linguistic project explicit.

49. Dryden, Works, IV: 413-14.

50. Dryden, Works, VI: 336.

51. Dryden, Works, V: 335 .

52. Dryden, Works, VI: 828-29. 
Dryden used the translations he published for and with Tonson as part of this personal project, but it must be remembered that his work was that of a writer-for-pay and his control was limited, especially after the Glorious Revolution, when Dryden relied on his translations for pecuniary gain. This does not, however, necessarily imply any diminishing of his poetic force or his literary schemes. As we see in his political career, Dryden is more than capable of pursuing more than one aim at a time. In fact, as Stephen Zwicker points out, "every one of Dryden's great poems was written to occasion." 53 The digressive, semi-formal writing style that he developed as a political tool is predicated on this type of dual focus, as are many of his most difficult and fascinating pieces. The relative simplicity of analogy in Absalom and Achitophel gives way to the complex blend of analogy, fable, confession, and religious and political commentary in The Hind and the Panther. Both of these writings, the latter often considered his most difficult work to interpret and the former his best piece of writing, were written to order at the request of a kingly patron.

The strategies he developed as a political writer show Dryden as an author who nearly always had more than one goal and more than one layer of meaning in his works, and these strategies continued to inform his translations, all of which show signs of literary experimentation. Even his Virgil, possibly the most financially-driven of all of his later writings, and which his contract required him to work on to the exclusion of any other major work, shows clear signs of Dryden's literary experimentation and crafting of linkages to the other works and poets which support his 'academy.' His work as a 'hack writer' is no more constrained by necessity than the political poems required of him as poet laureate. Instead, Dryden's financial necessity spurred him into a closer relationship with Tonson, making him one of the forerunners of modern author-public relations. Tonson, in turn, used the prestige and profit that Dryden brought him to make himself one of the foremost publishers of his day.

If he could not count on a titled sponsor for the public academy that he wished to create, Dryden was still able to rely on his bookseller,

53. Stephen Zwicker, "Introduction: A Tercentenary Tribute," in John Dryden: A Tercentenary Miscellany, ed. Susan Green and Steven Zwicker (California: Huntington Library, 2001), 2. 
Tonson, and his attempts were met with singular success. Dryden's work on linguistics was an influential part of a larger movement that began during this period, and Dryden was widely recognized by his contemporaries as a forerunner in the attempt to create a new status for the English language. A poem by Henry Hall in the 1690 claims that Dryden was one of the "first [who] our native language did refine," 54 and when Johnson wrote his 1779 "Life of Dryden," he ended the piece by showing that the capstone of Dryden's career was his linguistic legacy. "We owe," Johnson claims, "the improvement, perhaps the completion of our metre, the refinement of our language, and much of the correctness of our sentiments" to Dryden. ${ }^{55}$ This remarkable tribute shows that Dryden's efforts did not go unnoticed.

Dryden's literary legacy among his contemporaries was made possible by the translations and literary improvements that he carried out with Tonson's support, but their legacy in the marketplace, which provided a new venue for young poets attempting to break into print, is just as important to our understanding of Dryden's effect on print culture. The career of Alexander Pope, who first published in one of the Tonson miscellanies and ended by controlling every aspect of the publication of his own books, shows just one way in which Dryden's experimentation opened new doors to young poets and authors.

Of course, Tonson was not the kind of patron that Dryden originally hoped for, and his support of Dryden's project was due more to financial and political than to literary or linguistic considerations. But the fact remains that, with the support of his bookseller, Dryden made public many of his thoughts, hopes, and plans for improving the language, praised and supported other writers working to do the same, created a new medium for young authors, and helped to create the atmosphere in which Samuel Johnson could finally create the English dictionary and begin to codify linguistic rules. This project, which Dryden had been attempting to support for more than forty years,

54. Hall claims (as Dryden himself does in The Rival Ladies; see Works VIII: 100) that Dryden was following Waller, the first refiner of the language. See Henry Hall, “To Mr. Charles Hoskins upon my lending him Mr. Wallers Poems," (Leeds University Library Brotherton Collection, MS Lt q 5), 51, cited in Paul Hammond, "Contemporary References to Dryden," in John Dryden: Tercentenary Essays, ed. Paul Hammond and David Hopkins (Oxford: Oxford University Press, 2000), 388.

55. Johnson, Lives of the English Poets, I: 469. 
would not have been realized if he had not looked beyond traditional noble sources of patronage to the commercial world of his bookseller, seeing the potential in a new way of interacting with his publisher, and beginning the move toward a new method of support by booksellers and middle-class purchasers in place of noble patrons. 